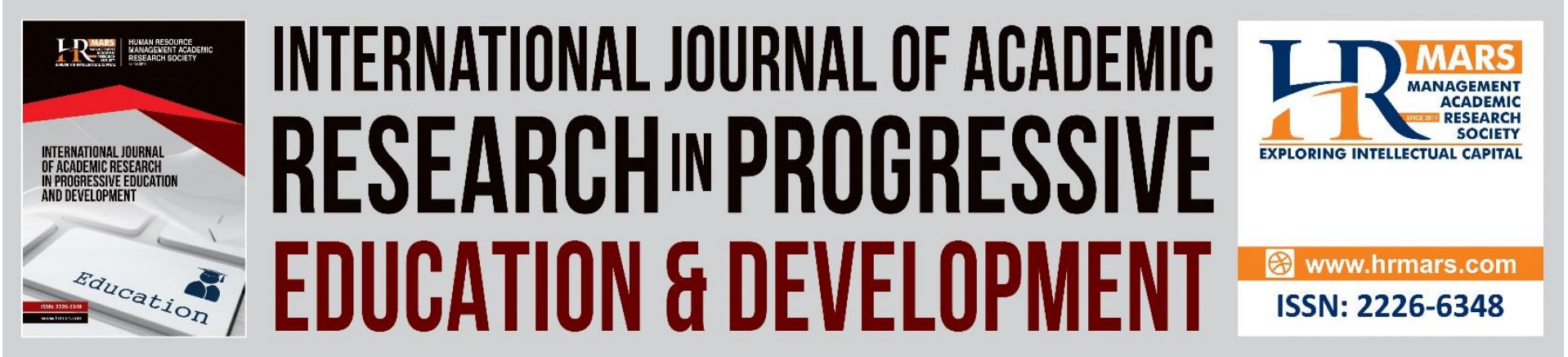

\title{
Revisiting the Laws and Policies Related to Educational Rights of Stateless Children in Malaysia
}

Nur Ezan Rahmat, Daleleer Kaur Randawar, Sheela Jayabalan, Muhammad Umar Abdul Razak \& Izuan Izzaidi Azmi

To Link this Article: http://dx.doi.org/10.6007/IJARPED/v10-i3/11261 DOI:10.6007/IJARPED/v10-i3/11261

Received: 09 July 2021, Revised: 25 July 2021, Accepted: 20 August 2021

Published Online: 21 September 2021

In-Text Citation: (Rahmat et al., 2021)

To Cite this Article: Rahmat, N. E., Randawar, D. K., Jayabalan, S., Razak, M. U. A., \& Azmi, I. I. (2021). Revisiting the Laws and Policies Related to Educational Rights of Stateless Children in Malaysia. International Journal of Academic Research in Progressive Education and Development, 10(3), 1174-1184.

Copyright: (C) 2021 The Author(s)

Published by Human Resource Management Academic Research Society (www.hrmars.com)

This article is published under the Creative Commons Attribution (CC BY 4.0) license. Anyone may reproduce, distribute, translate and create derivative works of this article (for both commercial and non-commercial purposes), subject to full attribution to the original publication and authors. The full terms of this license may be seen at: $\underline{\text { http://creativecommons.org/licences/by/4.0/legalcode }}$

\section{Vol. 10(3) 2021, Pg. 1174 - 1184}

Full Terms \& Conditions of access and use can be found at http://hrmars.com/index.php/pages/detail/publication-ethics 


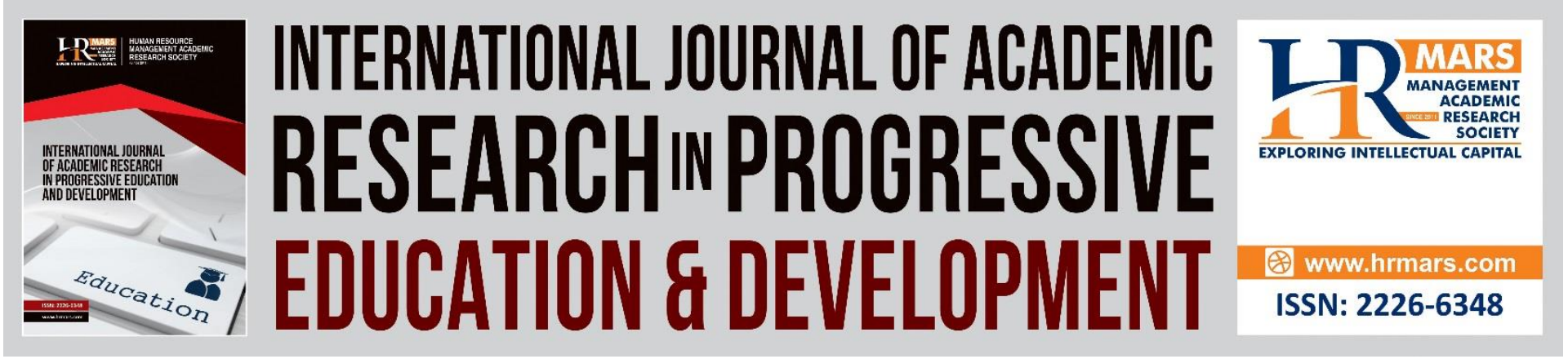

\title{
Revisiting the Laws and Policies Related to Educational Rights of Stateless Children in Malaysia
}

\author{
Nur Ezan Rahmat, Daleleer Kaur Randawar, Sheela \\ Jayabalan, Muhammad Umar Abdul Razak \& Izuan Izzaidi \\ Azmi \\ Faculty of Law, Universiti Teknologi MARA (UiTM), Shah Alam, Selangor, MALAYSIA
}

\begin{abstract}
Statelessness has been a substantial issue around the globe, yet the fact that stateless children in this country are struggling due to being deprived of rights to education is rarely discussed. This study is important as discrimination on the basis of ethnicity, gender, race or religion is the major cause of statelessness globally. In Malaysia, the laws and policies related to the educational rights of stateless children are clear, but the question is, are they adequate and sufficient? The objectives of this study is to revisit and scrutinise the laws and policies concerning the educational rights of stateless children in Malaysia, as well as to propose some amendments. This research employs qualitative research methodology with a doctrinal mechanism whereby the laws and policies have been revisited and examined. It is hoped that the findings of this research will lead the Malaysian government to amend the existing laws and policies related to the educational rights of stateless children; and to adopt the policy implemented by Thailand, which has allowed stateless children to enrol in public schools without any prerequisites. The future research could comparatively analyse and examine the laws in Thailand to be the benchmark in improving the current situation in Malaysia.
\end{abstract}

Keywords: Stateless Children, Educational Rights, Laws and Policies

\section{Introduction}

Education is a fundamental human right that is enshrined in many international conventions. Under Article 26 of the Universal Declaration of Human Rights (UDHR), it is stipulated that all persons shall have the right to free and compulsory education, at least in the elementary stages. Pursuant to Article 28 of the Convention on the Rights of the Child (CRC), state parties must make primary education compulsory and available to all, not only to those children who have citizenship but also to the stateless children. The 2015 United Nations High Commissioner of Refugees (UNCHR) report highlights how not being recognised as a national of any country can create insurmountable barriers to education and adequate health care and stifle job prospects. It reveals the devastating psychological toll of statelessness and its serious ramifications not only for young people, whose whole futures are before them, but also for 
their families, communities and countries. It demonstrates the urgency of ending and preventing childhood statelessness. This paper is revisiting the laws and policies related to the educational rights of stateless children to ensure their rights are protected and preserved. Education provides a wide range benefit for the individual gaining them, as well as to the societies. Limitations on accessing school perpetuate and magnifies challenges in the life of a person.

\section{Literature Review}

Every child indeed needs education because it denotes the providing of both basic and life skills (Porter, 2006). Pastoor (2016) gave an insight that mere access to education is insufficient and education must be made available to all, including refugees. Pastoor further highlighted that providing education is often beyond the UNHCR's capacity. A country's quality education system is vital to ensure a well-functioning society, including the stateless, and the only party who can realise this system efficiently is the government.

Children fall into a cycle of statelessness due to being orphaned, abandoned, illegitimate, the failure of marriage and birth registration, children of irregular migrants, and also being a child of refugees (Razali et. al, 2015). Although the Federal Constitution provides a robust legal safeguard against statelessness, it is flawed as it is strictly conditioned on proving the legality of marriage of the child's biological parents (Mohamed Razali, 2017). Although most authors agree that statelessness amongst children is a prevalent issue in Malaysia, Malaysia's existing citizenship law is still too general and fails to serve its purpose.

Several authors were concerned with the position of stateless children in Malaysia (Samad \& Affandi, 2018; Razali, 2017; Selvakumaran et. al, 2020; Hasni et al., 2021). It was suggested that Article 28(1) of the CRC is reserved due to its contravention with Article 12 of the Malaysian Federal Constitution. For limiting stateless children's enrolment into public school, the Human Rights Commission of Malaysia (SUHAKAM) expressed that as a country that is a state party to the CRC, the government must refrain from taking actions that could violate their human rights (SUHAKAM Report, 2018). This highlights the unfair position of these children and sparks concern about upholding their position in Malaysia.

Another point is the issue of discrimination faced by stateless children in Malaysia. The government was said to have shown concern by providing alternative learning opportunities for stateless children (Selvakumaran, 2020; Md Samad \& Mohd Badrol Affandi, 2018). They insisted that the discrimination against these children still subsist as these children are denied entry into public school. The Education Act 1966 had limited the rights to enter public school and implement compulsory primary school attendance only for citizens. There are two significant examples of discrimination suffered by stateless children in Malaysia reported by Chuah, 2016; Cheong \& Baltazar, 2021) and the UNHCR. Stateless children of Bajau Laut, Sabah, had to roam every day since they could not go to school. Other than that, a stateless boy became a substance of abuse because he was unable to enrol in public school. Children still have a lot to learn in life, but education deprivation has exposed them to crimes and unsuitable environments.

Numerous NGOs have tried their best in helping stateless children to receive an education. However, Md Samad \& Mohd Badrol Affandi (2018) contended that the NGOs are unable to make this available to all stateless children. The authors further included the government's 
response towards SUHAKAM's Annual Report 2015, which highlighted the establishment of twelve Alternative Learning Centres (ALC) for non-citizen children in collaboration with UNICEF. Selvakumaran et al (2020) have the opinion that for most of them, ALC is the only option since law and policy pertaining to stateless children in Malaysia have not yet been formally laid by the government. Nevertheless, UNICEF Malaysia (2019) finds ALC impracticable due to lack of certification, accreditation and its commercial value. Although the NGOs have tried hard to establish such education platforms, they are insufficient to provide education. Further research is needed to fill in this lacuna in Malaysian law.

There are a few initiatives for stateless children in Malaysia currently being carried out by the government. Firstly, the government established Sekolah Bimbingan Jalinan Kasih (SBJK), a school with an 'Education for All' concept (Annual Report, 2017). However, the pupils must have at least one Malaysian citizen parent to enrol in the said school. Hence, children with no Malaysian parents are still deprived of this benefit. Similarly, Samad \& Affandi (2018) highlighted the Professional Circular 1/2009 issued by the Ministry of Education, which has the same requirements regarding undocumented children's registration to enrol in public schools. The authors concluded that the essence of Articles 28 and 29 of the CRC are not fully applied within the Malaysian legal framework. This gives way for further research to be conducted to suggest relevant regulations and policies resolve the deprivation of rights suffered by stateless children with no Malaysian parents.

On top of that, in more than 30 countries, children must have nationality documentation to receive medical care (UNHCR Report, 2015). Since stateless children have no documentation in Malaysia, the government would impose full medical charges on them. The Malaysian government, in feedback for Human Rights Commission (SUHAKAM) 2017 and 2018 Annual Report, emphasised that every child, regardless of nationality, may acquire healthcare at any public health facilities (Ministry's Report, 2019). However, undocumented children are classified as foreigners and charged according to foreign patients' fee rates.

Stateless children's rights to education in other jurisdictions are also predominant in this study. An example of a foreign jurisdiction is Thailand, as it is one of the neighbouring countries that has signed the CRC where they were obliged to provide facilities and to fulfil the children's needs and their social welfare. This resulted that their government is to provide education for all children despite their nationality, which is imposed by the United Nations (Titiporn, 2019).

The literature review reveals that there is no specific writing or study that covers the adequacy or sufficiency of the current laws and policies related to the educational rights of stateless children in Malaysia. Hence, this paper aims to close the gap in the literature by revisiting the laws and policies regulating stateless children's right to education and to suggest specific regulations regarding stateless children's enrolment in public schools.

\section{Research Methodology}

Research methodology is a way to systematically solve the research problem, which involves a study of multiple steps and methods that a researcher generally needs to adopt and implement in the study (Abdullah, 2018). This research involves qualitative method, which relates to collecting and analysing non-numerical data. It is a doctrinal research in which the primary source of law is on legislations that closely govern the rights of education, such as the Malaysian Federal Constitution, Malaysian Education Act 1966, Thailand's National Education 
Act of 1999 and international laws to examine the position of stateless children in these legislations. The secondary sources of law used in this research consist of journal articles, online newspapers, cases, reports and conventions regarding stateless children and their rights to education, such as reports prepared by the UNHCR and the CRC. This approach was conducted to examine the current laws and policies governing stateless children's rights to education in Malaysia and other jurisdictions.

A comparative method was also used in this research, which involves comparisons of laws and policies governing stateless children and their rights to education in Malaysia and Thailand while making the law in Thailand as a benchmark for the amendments expected in Malaysian statutes and policies (Legal Dissertation, 2020). Thailand's development received compliments by several works of literature for acknowledging stateless children's rights to education as they mandated 15 years of free education for all children, regardless of Thai nationals or stateless children. The findings analysed from the doctrinal study was made by interpreting the legal texts and literature. This interpretation shall involve determining the meaning of such legal texts and works of literature and applying it to the real circumstances.

\section{The Position in Malaysia}

Article 1 of the UNHCR 's Convention Relating to the Status of Stateless Persons defines a 'stateless person' as a person who is not considered a national by any state's operation of law. Subsequently, this phenomenon of statelessness exists prevalently on the uttermost boundaries of international law and policy. The Convention highlights that a group of people is most vulnerable to become stateless when countries exercise their de facto authority in refusing to confer any nationality to certain persons within their territory (Menz, 2016). UNHCR once reported that there are approximately twelve million stateless people worldwide in 2009 under the states' operation of law, and it is further provided that the lack of systematic attention given to collect reliable statistics and consensus in counting stateless people had caused the figures for the stateless to be more speculative. The fact that this figure does not fully reflect the real number of stateless persons worldwide is mainly driven by the definition of a stateless person itself, whereby they live in the shadows on the outermost margins of society, thus undetected by most legal regimes (Menz, 2016; Cheong \& Baltazar, 2021).

Statelessness first came to prominence after World War II, where millions of refugees and stateless people had been stripped of their citizenship. This event results in drafting the UDHR, which essentially emphasises that "everyone has a right to a nationality" and "no one shall be arbitrarily deprived of his nationality" (Berkeley, 2009). It was reported by UNHCR that there are approximately twelve million stateless people worldwide in 2009 under the states' operation of law, and it is further provided that the lack of systematic attention given to collect reliable statistics and consensus in counting stateless people had caused the figures for the stateless to be more speculative. The fact that this figure does not fully reflect the real number of stateless persons worldwide is mainly driven by the definition of a stateless person itself, whereby they live in the shadows on the outermost margins of society, thus undetected by most legal regimes (Menz, 2016).

Since statelessness correlates directly with the absence of legal identification, the absence of birth registration had become the leading cause that had led to this problem. Birth certificates 
are important for children as it provides permanent, official, and visible evidence of a state's legal recognition of their existence as a member of society. Without any birth certificate, it is more likely that the child would be unclaimed by any state. The failure to give a child its birth certificate or deny access to register the birth of a child shall amount to a state's discriminatory act, which would further contribute to the hike in statelessness (Ujvari, 2017).

In Malaysia, there are roughly six classifications of stateless persons and four main groups of people described as either stateless or at the risk of being stateless which are Malaysians of Indian descent, members of the traditionally nomadic, Bajau Laut community, the children of refugees and migrants in Sabah, North Borneo, and Rohingya refugees from Myanmar (Liew, 2019; Allerton, 2014). The legal status of the children in Sabah, especially, is very complicated to be determined. A sample study conducted by the MOE under Article 28(1) CRC in 2009 found that there were 43,973 undocumented children in Malaysia, aged 7 to 17 years old, who are out-of-school (Allerton, 2014). The number only represents those who were not in school; therefore, the actual number was not identified. Referring to UNHCR Report on statelessness, although undocumented children are identified as those who lack birth registration, they are not equivalent to being stateless; it only will enhance the risk of statelessness.

There are several common reasons for statelessness to occur in Malaysia (Samad \& Affandi, 2018). New parents typically fail to register their marriage and the child's birth because they lack of knowledge on the importance of their marriage registration in Malaysia towards the child's citizenship (Liew, 2019). It is clear that statelessness relates to not having citizenship from any country. The word citizenship is defined as being a member of a particular country and having rights due to that fact (Cambridge Dictionary). Therefore, it is evident that statelessness in this country is closely related to the citizenship law.

Generally, there are four main ways incorporated in the Malaysian Federal Constitution on how a person may receive citizenship, which includes by way of operation of law (Article 14), by registration (Article 15, Article 15A, Article 16, Article 16A), by naturalisation as in Article 19 , and by incorporation of territory under Article 22. According to Article 14(1)(b), a person gains citizenship automatically by law if born on or after Malaysia Day, having at least a parent who is a Malaysian citizen or a permanent resident. However, if a child is born in a family where the parents are not legally married, they will attain their mother's citizenship (Liew, 2019). This means that even if an illegitimate child has a Malaysian father, the child is still not entitled to gain citizenship, bringing the child at risk of statelessness if the mother is stateless as well. In a 2015 unreported case, a judge ruled that the boy should adopt his birth mother's Thai nationality since his parents were not married during his birth. The court considered that it was insignificant that the boy's mother vanished when he was six months old and was never tracked down (Liew, 2019).

People may also gain citizenship through registration, where Article 15 specifies on wives and children of citizens. On top of that, as emphasised in Article 15A, the Federal Government has the discretionary power to grant citizenship to anyone who is less than 21 years old. Among the rights that these stateless children are deprived of is the right to education. Stateless 
children do not acquire formal education rights because government schools do not generally accept non-Malaysian or undocumented children (Che Soh @ Yusoff, 2019).

Article 14 of the Federal Constitution elaborates how a person may gain citizenship automatically by law. Under Article 14(1)(a), if a person is born before Malaysia Day, he will automatically attain citizenship by virtue of provisions in Part I of the Second Schedule, which incorporates jus soli (nationality by birth) and jus sanguinis (nationality by blood). Meanwhile, Article 14(1)(b) highlights that when a person is born on or after Malaysia day and is qualified based on Part II of Schedule II, he may attain citizenship. Part II of Schedule II emphasises the citizenship of at least one parent, incorporating jus sanguinis. The case of Madhuvita Janjara Augustine (Suing through next of friend, Margaret Louisa Tan) v Augustin A/L Lourdasmy \&Ors [2018] 1 MLJ 307 reflects the court decision in upholding the child as a citizen by operation of law under Article 14(1)(b) which is read with Part II Section(1)(a) where one of his parents at the time of his birth was either a citizen or a permanent resident. In contrast with the case of Registrar of Birth and Death v Pang Wee Swee \& Anor. [2017] 7 CL 33, citizenship was not granted even though the child's adoptive parents were Malaysians since the child's biological parents are untraceable, leading to the failure in fulfilling the requirements under Article 14(1)(b) (Selvakumaran et al., 2020)

As to the educational rights, referring to the general law, Article 12(1) of the Federal Constitution states that without prejudice to the generality of Article 8 (all persons are equal before the law and entitled to the law's equal protection), there should be no discrimination against any citizen on the grounds only of religion, race, descent or place of birth which is:

(a) in the administration of any educational institution maintained by a public authority, and the admission of pupils or students or the payment of fees; or (b) in providing out of the funds of a public authority financial aid for pupils or students' maintenance or education in any educational institution (whether maintained by a public authority and whether within or outside the Federation).

By reading Article 12 together with Article 8 , Article 12 puts limitations towards applying Article 8 regarding educational rights since the provision focuses on Malaysian children. This provision opens the possibility to discriminate stateless children on their rights to education and cause them to be left behind (Samad \& Affandi, 2018).

Malaysia's attempt to protect children's main interest is by implementing the Child Act 2001. This act was enacted based on the principles laid down in the Convention on the Rights of the Child (CRC), which is meant to protect children's welfare in Malaysia (Taib, 2012). Although this act's preamble intends to protect children without discrimination, it does not adequately address children's access to general education. On the other hand, the preamble of the Malaysian Education Act 1966 emphasises an education's purpose in enabling the Malaysian society to command knowledge. The term 'Malaysian society' is suggested to refer to those with Malaysian citizenship only, making the stateless children excluded from this Act (Samad \& Affandi, 2018). Under section 27 of the Education Act 1996, the Minister has an obligation to provide for primary schools, while section 29A emphasises that primary education is compulsory, and it imposes an obligation to parents in ensuring their child attends primary education, or else it is an offence. However, the 'parents' referred to in section 29A only limits 
to Malaysian citizens, meaning that compulsory education does not include stateless children with non-citizen parents. Even with the Education Act 1996, stateless and undocumented children are deprived of education rights since they lack documentation. Therefore, reading the preamble of the Child Act 2001, together with the provisions discussed, Malaysian legislations acknowledge the equity and equality for all children in Malaysia to obtain an education without discrimination only to Malaysian citizens. This acknowledgement should be extended to the stateless children in Malaysia since they deserve the right to education too.

In the effort of complying with United Nations Educational, Scientific and Cultural Organization (UNESCO) concept of Education for All, the Ministry of Education (MOE) had introduced a Compulsory Education Policy together with circular letters, and among them is the Professional Circular Letter No. 1/2009 dated 11 March 2009 (MOE website). The issuance of Professional Circular Letter No. 1/2009 allows undocumented children with at least a Malaysian citizen parent to enrol in public schools or government aid schools (Ministry Report, 2019). A testimonial letter from the Head of Village that testifies that the child is a Malaysian also needs to be included alongside the school application (Samad \& Affandi, 2018).

The Zero Reject Policy was introduced by the MOE in 2018 as a corrective measure. The policy implementation took place in 2019 when the Education Minister at that time highlighted that this policy ensured that special needs and undocumented children would have access to education and not being left out of schooling (Abdul Rashid, 2018). Four months after its implementation, a record of 2635 undocumented children was enrolled in schools. This indicated that the corrective measure had positively affected school admission for many undocumented children and save them from becoming misfits in society, and thus gave hope for a brighter future. However, when the new government took over the administration in early 2020, this policy was stopped due to some reasons.

\section{The Position in Thailand}

Although the exact number of stateless people in each country is not recorded, Thailand is roughly ranked as the fourth country with many stateless people while Malaysia is ranked $16^{\text {th }}$ (Worster, 2019). However, Thailand undertakes to consider further changes to Thailand's Nationality Act and include better access to birth registration and person documentation facilities, including late birth registration, to expand on Thailand's success in reducing stateless vulnerability (United Nations High Commissioner of Refugees, 2013). There are three main legislations that govern the citizenship rights in Thailand; the Civil Registration Act, Nationality Act and the Immigration Act, but these legislations do not define precisely the concept of citizenship or statelessness.

The Civil Registration Act 2008 of Thailand provides that every child born in the country, regardless of their parents' status, will be given an official birth certificate (Thailand Annual Human Rights Report, 2010). This would allow them to remain in the country and have access to basic needs such as education and health care.

All children in Thailand attain the right to education, regardless of their legal status. The Government of Thailand has formulated and implemented a number of progressive policies. In 2005, the Royal Thai Government Cabinet Resolution for Unregistered Persons had led to 
the availability of rights to an education at all levels for children with a lack of legal status in Thailand (Thai National Commission for UNESCO, 2014). Education programmes are open for stateless children at every level in public and private institutions, with the issuance of academic credentials upon completion.

The primary education for stateless children in Thailand was also said to be compulsory, free and universal. Furthermore, Titiporn et al (2019) highlighted that Thailand's Ministry of Education has mandated in the 1997 Constitution that all children have the right to twelve years of free, quality primary education with the first nine years being compulsory as provided in Thailand's National Education Act of 1999. On top of that, a policy invented by the Thailand government was also mentioned where the schools were reimbursed the education fee for each migrant child based on a specified and equal rate to a Thai child. Thailand also has established Migrant Learning Centres (MLC) where migrant parents can send their children for education there (Titiporn et al., 2019).

These inclusive frameworks and legislations by the Thai government had resulted in numerous schools that are situated in the marginalised areas complying with the nine years of compulsory education as stipulated in Thailand's National Education Act 1999 and have received special assistance by the ministry to deliver better ways in educating the children by providing multilingual teaching to those children who cannot speak Thai language. Rights to education in Thailand had always been embedded by the Education for All policy, which is the root of allowing access free quality primary education to all children, including the stateless.

Thailand's willingness to improve their laws and policies for the stateless emphasises the importance of education for every child, and even with a strict citizenship law, it is not impossible to give the children their rights to education. This step should be followed by other countries in upholding that nobody should be left behind especially in education.

\section{Conclusion and Recommendations}

After analysing and examining the laws and policies in Malaysia, this study finds that the stateless children's education rights in Malaysia's public education system are not prevalent. In other words, their educational rights are not fully protected. Although the Malaysian government had started to include undocumented children's access into the public education system through Zero Reject Policy (2019), the endeavours are yet to include majority groups of stateless children living in Malaysia. A more comprehensive policy can be created and used as a guideline for school admission of stateless children. This study also suggests that improvement should be made to the existing 2019 Policy and the Professional Circular 1/2009 to include access for stateless children without citizenship of the parent(s). Furthermore, it is also relevant to encourage Malaysia's MoE to analyse and adapt the education programmes and policies governing stateless children in our neighbouring country, Thailand. It can assist the government in counting and tracking the exact number of stateless children in our nation through their school admission. As a continuation of the informal education initiatives provided by various NGOs for stateless children below 18, the universities should begin by opening entrance exams to these stateless candidates. These candidates must fulfil all admission requirements for the academic programme corresponding to the university programme they wish to enrol in. 


\section{Acknowledgement}

The authors would like to express appreciation to the Faculty of Law, Universiti Teknologi MARA (UiTM) for the financial support in publishing this paper.

\section{References}

Abdullah, N. (2018). Legal Research Methodology. Thomson Reuters Asia Sdn Bhd. 161.

Berkeley, B. (2009). Stateless People, Violent States. World Policy Journal, 26(1), 3-15. http://www.jstor.org/stable/40210101

Cheong, A. R., \& Baltazar, M. A. (2021). Too precarious to walk: An integrated "Three delays" framework for modeling barriers to maternal health care and birth registration among stateless persons and Irregular migrants in Malaysia. Genus, 77(1). https://doi.org/10.1186/s41118-021-00129-3

de Wal Pastoor, L. (2016). Rethinking refugee education: Principles, policies and practice from a European perspective. Annual Review of Comparative and International Education 2016, 107-116. https://doi.org/10.1108/s1479-367920160000030009

Hasni, N. A. S., Azman, N., \& Ismail, M. N. (2021). Stateless Children's Access to Tertiary Education. Selangor Humaniora Review, 5(1), 30-39. Retrieved from http://share.journals.unisel.edu.my/ojs/index.php/share/article/view/133

Liew, J. (2019). Homegrown statelessness in Malaysia: The administratively stateless and the promise of the principle of genuine and effective links. Statelessness \& Citizenship Review, 1(1), 95-135. https://doi.org/10.35715/scr1001.115

Saman, M., \& Afandi, M. B. N. H. (2018). Honoring primary education for stateless children: Analysis of Malaysian legal perspective and current practice. IIUM Repository (IRep). Retrieved September 21, 2021, from http://irep.iium.edu.my/id/eprint/67203.

Razali, M. R., Nordin, R., \& Duraisingam, T. (2015). Migration and Statelessness: Turning the Spotlight on Malaysia. Pertanika Journal of Social Science and Humanities. 23(S). 19-36.

Razali, M. R. (2017). Addressing Statelessness in Malaysia: New Hope and Remaining Challenges. Statelessness Working Paper Series No. 2017/06, 5th Edition. 3 - 10. 10.13140/RG.2.2.27827.99363.

Porter, L. (2006). Illegal immigrants should not receive social services. International Social Science Review, 81(1/2), 66-72. http://www.jstor.org/stable/41887261

Selvakumaran, K., Tie, F. H., \& Yusoff, J. Z. M. (1970, January 1). A legal perspective on the right to education for stateless children in selected ASEAN countries. UM Research Repository. Retrieved September 21, 2021, from http://eprints.um.edu.my/id/eprint/24987.

Tuangratananon, T., Suphanchaimat, R., Julchoo, S., Sinam, P., \& Putthasri, W. (2019). Education policy for migrant children in Thailand and how it really happens; a case study Of RANONG Province, Thailand. International Journal of Environmental Research and Public Health, 16(3), 430. https://doi.org/10.3390/ijerph16030430

Ujvári, B. (2017). The causes of statelessness. Hungarian Yearbook of International Law and European Law, 5(1), 105-113. https://doi.org/10.5553/hyiel/266627012017005001006

Worster, W. T. (2019). The obligation to grant nationality to stateless children under customary international law. Michigan State International Law Review, vol 27(3). 469. 
INTERNATIONAL JOURNAL OF ACADEMIC RESEARCH IN PROGRESSIVE EDUCATION AND DEVELOPMENT

Vol. 10, No. 3, 2021, E-ISSN: 2226-6348 @ 2021 HRMARS

Yusoff, R. C., Afandi, N. H., Hashim, N. M., \& Hak, N. A. (2019). Protecting the Children's right to nationality in Malaysia: An appraisal. International Journal of Academic Research in Business and Social Sciences, 9(6). https://doi.org/10.6007/ijarbss/v9-i6/5956 